\title{
Squamous cell carcinoma of the eyelid masquerading as 'malignant' ophthalmopathy of Graves's disease
}

\author{
H. C. FORD, ${ }^{1}$ J. W. DELAHUNT, ${ }^{2}$ and C. A. TEAGUE 1
}

From the Departments of ${ }^{1}$ Pathology and ${ }^{2}$ Medicine, Wellington Clinical School of Medicine, Wellington, New Zealand

SUMmary A patient with Graves's disease is described in whom the periorbital changes of severe ophthalmopathy and iatrogenic Cushing's syndrome delayed the diagnosis of a squamous cell carcinoma of the eyelid. It is suggested that the immunosuppressive therapy which the patient received may have enhanced the growth of a pre-existing malignancy.

Progressive inflammation of the orbital tissue occurs in less than $3 \%$ of patients with Graves's disease. ${ }^{12}$ In severe cases glucocorticoid treatment is indicated, ${ }^{3}$ and immunosuppression with azathioprine ${ }^{4-7}$ and cyclophosphamide ${ }^{89}$ has also been used by some groups, with or without plasmapheresis.

In immunosuppressed patients the incidence of malignant neoplasms is markedly increased. ${ }^{10} \mathrm{~A}$ large proportion of these tumours are skin cancers, which may develop within 4 months of the initiation of

Correspondence to Dr H. C. Ford, Department of Pathology, Wellington Clinical School of Medicine, Wellington Hospital, Wellington 2, New Zealand. immunosuppressive therapy. ${ }^{11-15}$ Basal cell carcinomas are the predominant type of skin cancer in the general population; however, in the immunosuppressed patient the majority are squamous cell.

We describe a patient with Graves's ophthalmopathy of sufficient severity to warrant treatment with azathioprine and prednisone, in whom the presence of a squamous cell carcinoma of one lower eyelid was not promptly recognised as a factor contributing to the retraction and inflammation of the lid. The diagnostic difficulties that were encountered and the possibility that the high doses of immunosuppressive drugs that the patient received accelerated tumour growth prompted us to offer the following case report.

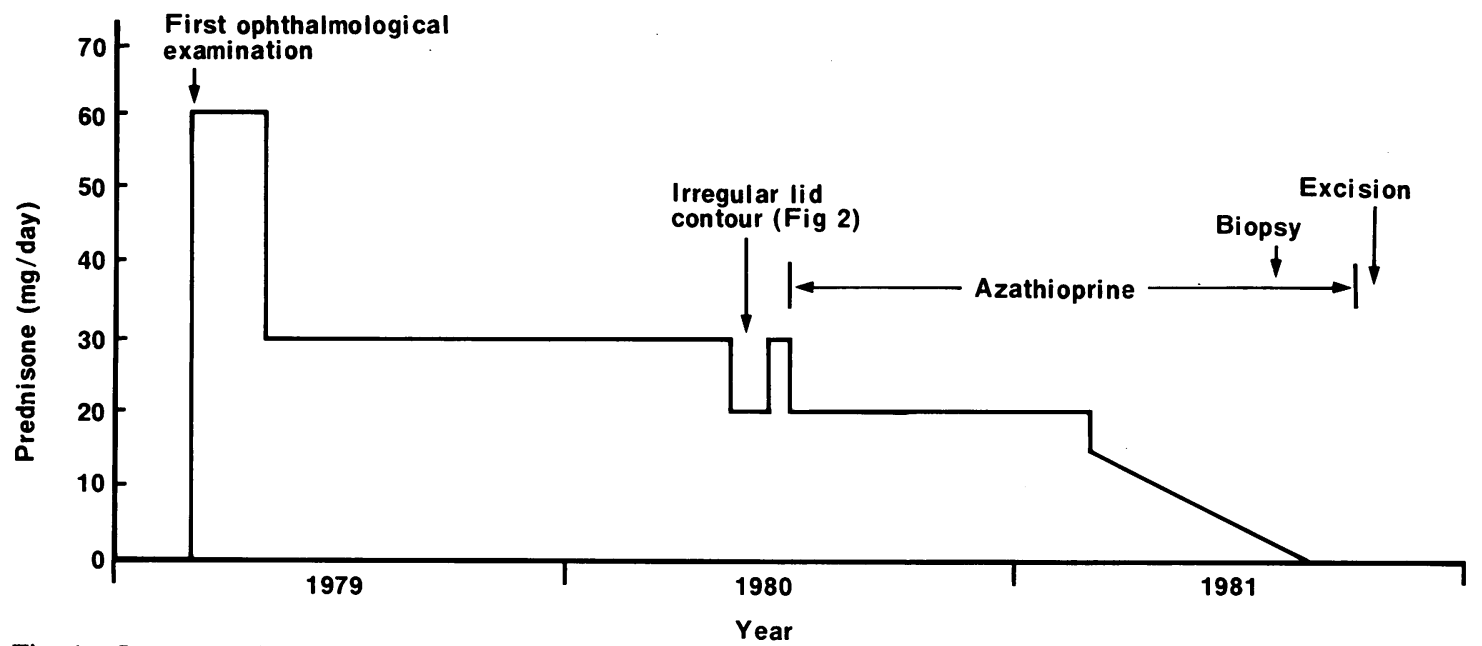

Fig. 1 Summary of the patient's course and treatment. 

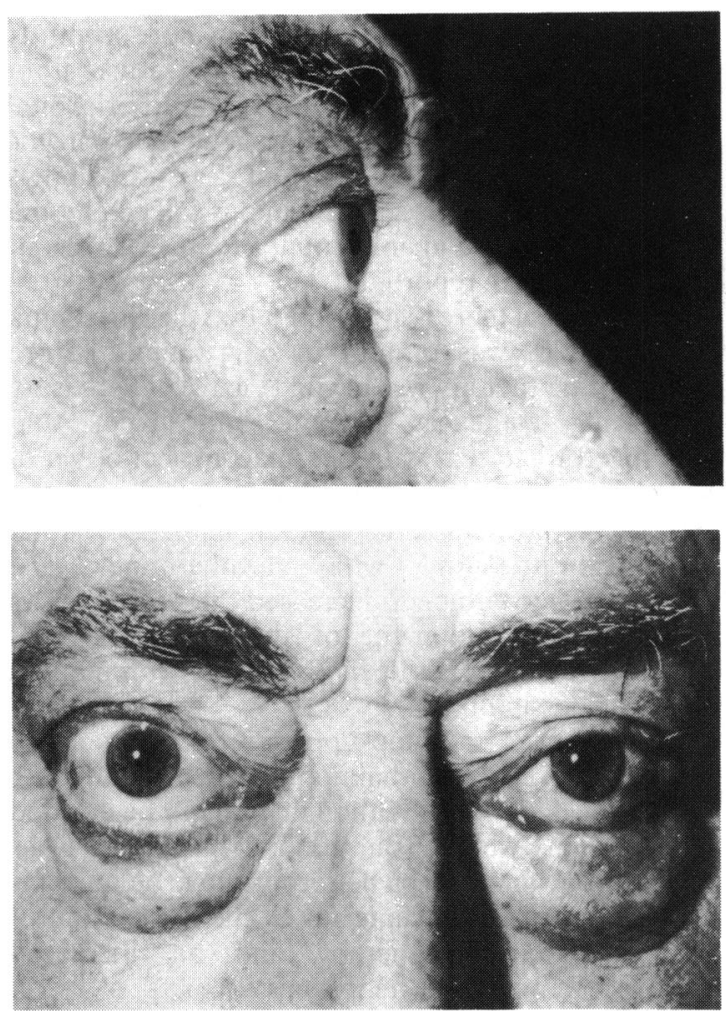

\section{Case report}

The patient, a 59-year-old male construction foreman, was first discovered to be hyperthyroid in August 1978 after 2 months of symptoms which did not include eye complaints. He was initially treated with carbimazole and propranolol, and first received ${ }^{131} \mathrm{I}(10 \mathrm{mCi})$ in November 1978 . Because of biochemical evidence of recurrent hyperthyroidism, further treatment with radioiodine was given in April $1980(10 \mathrm{mCi})$, October $1980(15 \mathrm{mCi})$, and July 1981 $(20 \mathrm{mCi})$. During this time thyroid function was maintained largely within normal biochemical limits with appropriate doses of carbimazole. With occasional minor exceptions the levels of thyroid stimulating hormone remained within normal limits.

He was admitted to the hospital in February 1979 with a history of progressive exophthalmos associated with a painful, gritty sensation of the eyes and photophobia (Fig. 1). There was moderate proptosis, oedema of the periorbital tissues, especially the lower lids, chemosis, and slight limitation of upward gaze bilaterally. The conjunctivae were inflamed and were very boggy and swollen near the inner canthus. No specific abnormalities of the left lower eyelid were noted. There was no change in visual acuity and no papilloedema. Prednisone $(60 \mathrm{mg} / \mathrm{day})$ was admin-

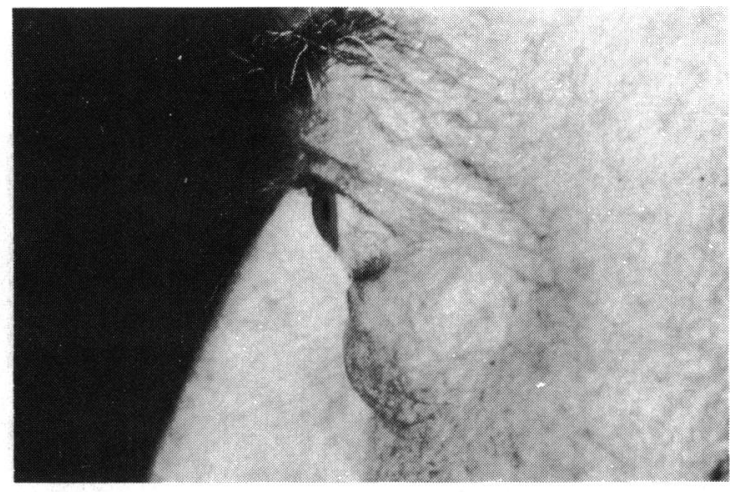

Fig. 2 The patient, May 1980. Swelling of the periorbital tissue, exophthalmos and chronic inflammatory changes of the conjunctivae are evident. The contour of the left lower lid margin is lost and the surrounding skin has a glistening, irregular appearance.

istered and was followed by a decrease in proptosis bilaterally (23-22 mm right eye and $24-21 \mathrm{~mm}$ left eye, measured with a Hertel ophthalmometer). Over the next several months the dose of prednisone was decreased to $30 \mathrm{mg} /$ day, with little change in the eyes. In May 1980 prednisone was decreased to $20 \mathrm{mg}$ daily, but this was associated with an increase in proptosis, conjunctival injection, and eye pain (Fig. 2).

In June 1980 azathioprine therapy was begun at a daily dose of $150 \mathrm{mg} /$ day $(1.7 \mathrm{mg} / \mathrm{kg})$ and was increased to $200 \mathrm{mg} /$ day in September 1980; prednisone $(20 \mathrm{mg} /$ day $)$ was continued. Because it was considered that the eye changes were entering a more chronic stage, the prednisone treatment was gradually discontinued over the ensuing months. There was little change in the eye signs except for a dimunition in periorbital fullness associated with disappearance of the Cushingoid facies. The scleral conjunctivae were thickened and were markedly inflamed and oedematous at the inner canthus bilaterally. As the Cushingoid facies regressed, asymmetry of lid retraction and irregularity of the contour of the left lid margin became more apparent.

In September 1981 azathioprine therapy was discontinued, and the left lower lid was biopsied and subsequently excised and replaced. Pathological examination showed a moderately differentiated 


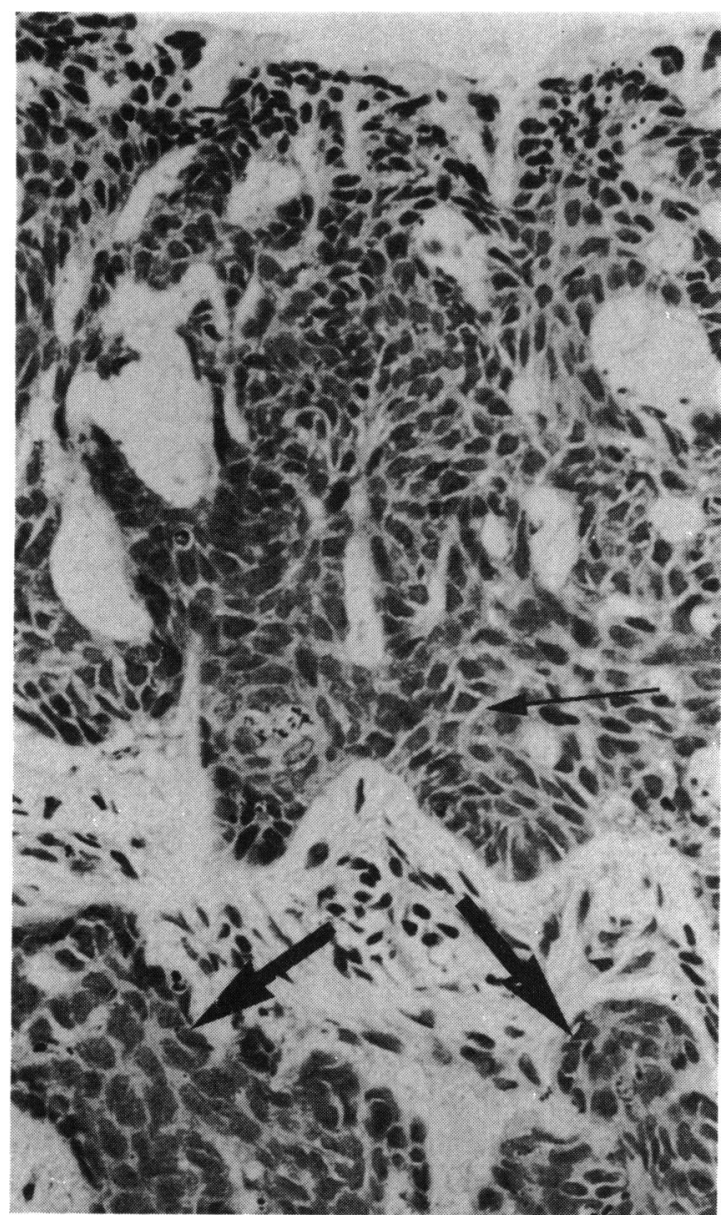

Fig. 3 Photomicrograph of a representative area of the eyelid biopsy. The surface epithelium (above) is replaced by disorganised bands of pleomorphic hyperchromatic squamous carcinoma cells showing intercellular 'prickles' (small arrow). Islands of carcinoma (large arrows) are seen in the adjacent connective tissue. (Haematoxylin and eosin, $\times 300$ ).

nonkeratinising squamous cell carcinoma of the lower lid with invasion of the adjacent connective tissue (Fig. 3).

The patient is currently receiving a replacement dose of thyroxine. There is moderate exophthalmos, but visual acuity is unchanged, and range of motion of the eyes is full (Fig. 4). There is no evidence of tumour recurrence.

\section{Discussion}

Squamous cell carcinoma of the eyelid is an unusual tumour occurring with about one-fortieth the frequency of basal cell carcinoma. ${ }^{1617}$ The presence of the tumour in our patient was not promptly recognised-in part because it was infiltrative rather than papillomatous. ${ }^{16}$ Moreover, the periorbital changes were at first attributed to acute and chronic Graves's ophthalmopathy and to Cushing's syndrome. Another case of squamous cell carcinoma of the left lower lid in an immunosuppressed patient has recently been reported. ${ }^{18}$

In retrospect there is little doubt that the carcinoma of the eyelid was present in our patient before azathioprine therapy was begun (Fig. 2). There is no convincing evidence, to our knowledge, that prolonged treatment with pharmacological doses of glucocorticoid alone increases the risk of the development of epithelial tumours in man. Whether immunosuppression with azathioprine and prednisone combined increased the chance of unhindered development of the malignant cells already present, as has been suggested, ${ }^{11}{ }^{14}$ remains a worrying possibility.

The role of immunosuppressive treatment in severe Graves's ophthalmopathy is undergoing evaluation at present. ${ }^{1}$ Although it cannot be decided with certainty whether our patient's skin cancer was enhanced by the therapy he received, we believe it is important to remind clinicians of the association of immunosuppressive therapy and an increased incidence of malignant neoplasms.

We thank Mr P. C. Herrick, ophthalmologist, Wellington Hospital, for assistance, and Mrs N. Painton for typing the manuscript.

\section{References}

1 Wall JR, Henderson J, Strakosch CR, Joyner DM. Graves' ophthalmopathy. Can Med Assoc J 1981; 124: 855-66.

2 Hamilton RD, Mayberry WE, McConahey WM, Hanson KC Ophthalmopathy of Graves' disease: a comparison between patients treated surgically and patients treated with radioiodide. Mayo Clin Proc 1967; 42: 812-8.

3 Werner SC. Prednisone in emergency treatment of malignant exophthalmos. Lancet 1966; i: 1004-7.

4 Burrow GN, Mitchell MS, Howard RO, Morrow LB. Immunosuppressive therapy for the eye changes of Graves' disease. J Clin Endocrinol Metab 1970; 31: 307-11

5 Winand $R$, Mahieu P. Prevention of malignant exophthalmos after treatment of thyrotoxicosis. Lancet 1973; i: 1196.

6 Dandona P, Marshall N, Bidey S, Nathan AW, Havard CWH. Treatment of acute malignant exophthalmos with plasma exchange. In: Stockigt JR, Nagataki S, eds. Thyroid research VIII. Canberra: Australian Academy of Science, 1980: 583.

7 Dandona P, Marshall NJ, Bidey SP, Nathan A, Havard CWH Successful treatment of exophthalmos and pretibial myxoedema with plasmapheresis. Br Med J 1979; i: 374-6.

8 Wall JR, Strakosch CR, Fang SL, Ingbar SH, Braverman LE. Thyroid binding antibodies and other immunological abnormalities in patients with Graves' ophthalmopathy: effect of treatment with cyclophosphamide. Clin Endocrinol 1979; 10: 79-91.

9 Bigos ST, Nisula BC, Daniels GH, Eastman RC, Johnston HH Kohler PO. Cyclophosphamide in the management of advanced Graves' ophthalmopathy. Ann Intern Med 1979; 90: 921-3. 

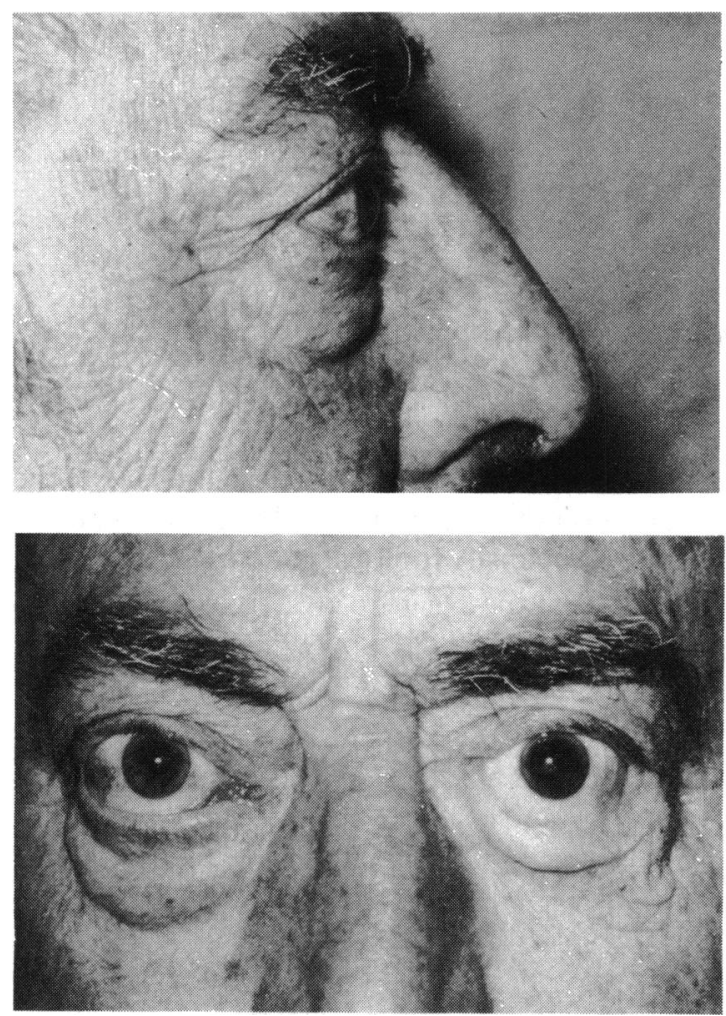

10 Penn I. Development of cancer as a complication of clinical transplantation. Transplant Proc 1977; 9: 1121-7.

11 Walder BK, Robertson MR, Jeremy D. Skin cancer and immunosuppression. Lancet 1971; ii: 1282-3.

12 Westburg SP, Stone OJ. Multiple cutaneous squamous cell carcinomas during immunosuppressive therapy. Arch Dermatol 1973; 107: 893-5.

13 Marshall V. Premalignant and malignant skin tumours in immunosuppressed patients. Transplantation 1974; 17: 272-5.

14 Maize JC. Skin cancer in immunosuppressed patients. JAMA 1977; 237: 1857-8.

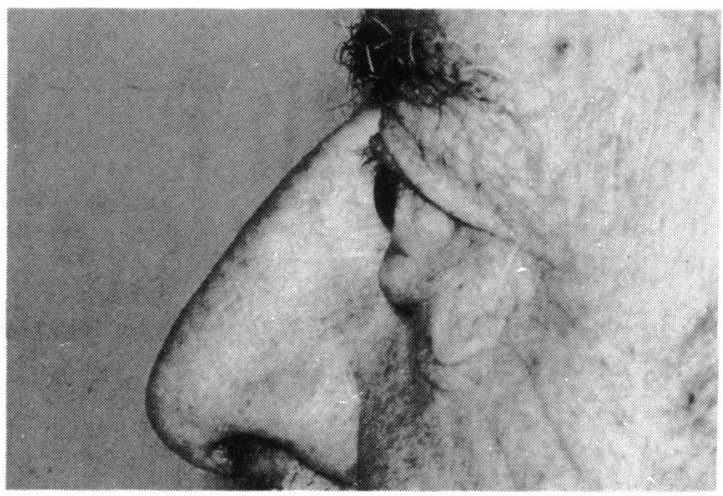

Fig. 4 The patient, February 1983, 17 months after excision of the tumour and reconstruction of the left lower lid.

15 Hoxtell EO, Mandel JS, Murray SS, Schuman LM, Goltz RW Incidence of skin carcinoma after renal transplantation. Arch Dermatol 1977; 113: 436-8.

16 Duke-Elder S, MacFaul PA. The ocular adnexa. In: Duke-Elder S, ed. System of ophthalmology. London: Kimpton, 1974: 13: 420.

17 Yanoff M, Fine BS. Ocular pathology: $a$ text and atlas. Hagerstown: Harper and Row, 1975: 214.

18 Stewart WB, Nicholson DH, Hamilton G, Tenzel RR, Spencer WH. Eyelid tumors and renal transplantation. Arch Ophthalmol 1980; 98: 1771-2. 